\title{
HUBUNGAN PERSONAL HYGIENE DENGAN KEJADIAN DEMAM THYPOID DI POLI RAWAT JALAN RUMAH SAKIT BHAYANGKARA PALEMBANG TAHUN 2019
}

\author{
Zuhana Hayun ${ }^{1}$, Fermanda Fitri Wulandari ${ }^{2}$ \\ 1. Dosen STIK Siti Khadijah Palembang \\ 2. STIK Siti Khadijah Palembang \\ Email : zuhanahayun78@gmail.com
}

\begin{abstract}
ABSTRAK
Demam tifoid atau thypus abdominalis adalah penyakit infeksi akut yang biasanya mengenai saluran pencernaan dengan gejala demam lebih dari 7 hari, gangguan pada saluran cerna dan gangguan kesadaran. Secara global diperkirakan setiap tahunnya terjadi sekitar 21 juta kasus dan 222.000 menyebabkan kematian. Penyakit ini erat kaitannya dengan hygiene pribadi dan sanitasi lingkungan, seperti higiene perorangan, hygiene makanan, lingkungan yang kumuh, kebersihan tempat-tempat umum. Tujuan penelitian ini adalah untuk mengetahui hubungan personal hygiene dengan kejadian demam typhoid di Poli Rawat Jalan rumah sakit bhayangkara palembang tahun 2019. Jenis penelitian ini adalah survey analitik dengan pendekatan cross sectional. Sampel diambil dengan teknik accidental sampling sebanyak 87 responden. penelitian ini dilaksankana di Poli Rawat Jalan Rumah Sakit Bhayangkara Palembang pada 22 Juli - 10 Agustus 2019 Analisa data menggunakan analisa univariat dan bivariat. Hasil penelitian didapatkan responden yang mengalami demam thypoid sebanyak 38 responden (43,7\%), responden personal hygiene kurang baik sebanyak 29 responden (33,3\%). Hasil uji chi square diketahui bahwa ada hubungan personal hygiene dengan kejadian demam thypoid di Poli Rawat Jalan Rumah Sakit Bhayangkara Palembang tahun 2019 dengan $p$ value $=0,002$. Diharapkan rumah sakit dapat meningkatkan pemberian informasi kepada masyarakat tentang personal hygiene dengan memperbanyak foster-foster tentang cara menjaga kebersihan diri, penyuluhan atau konseling serta dapat meningkatkan pemberian layanan kepada pasien thypoid.

Kata Kunci : Thypoid, Personal Hygiene

Referensi : $19(2015-2019$
\end{abstract}

\begin{abstract}
Typhoid fever or abdominal thypus is an acute infectious disease that usually affects the digestive tract with symptoms of fever for more than 7 days, disorders of the gastrointestinal tract and disturbance of consciousness. Globally, an estimated 21 million cases occur each year and 222,000 cause deaths. This disease is closely related to personal hygiene and environmental sanitation, such as personal hygiene, food hygiene, dirty environment, cleanliness of public places. The purpose of this study was to determine the correlation of personal hygiene with the incidence of typhoid fever in Outpatient Clinic Bhayangkara Hospital in Palembang in 2019. This type of research is an analytical survey with cross sectional approach. Samples were taken by accidental sampling technique as many as 87 respondents. This research was carried out in the Outpatient Clinic of Bhayangkara Hospital Palembang on 22 July - 10 August 2019 Data analysis used univariate and bivariate analysis. The results obtained by respondents who experienced typhoid fever as many as 38 respondents (43.7\%), respondents less good personal
\end{abstract}


hygiene as many as 29 respondents (33.3\%). Chi square test results are known that there is a relationship of personal hygiene with the incidence of typhoid fever in Outpatient Clinic of Bhayangkara Hospital Palembang in 2019 with $p$ value $=0.002$. It is expected that hospitals can increase the provision of information to the public about personal hygiene by increasing foster-foster about how to maintain personal hygiene, counseling or counseling and can improve the provision of services to typhoid patients.

\section{Keywords : Thypoid Fever, Personal Hygiene \\ References : $19(2015-2019)$}

\section{PENDAHULUAN}

Demam tifoid atau thypus abdominalis merupakan penyakit infeksi akut yang biasanya mengenai saluran pencernaan dengan gejala demam lebih dari 7 hari, gangguan pada saluran cerna dan gangguan kesadaran. Dalam masyarakat penyakit ini dikenal dengan nama Tipes atau thypus. Penyakit ini disebabkan oleh salmonella typhosa dan hanya didapatkan pada manusia. Penularan penyakit ini hampir selalu terjadi melalui makanan dan minuman yang terkontaminasi (T.H.Rampengan,2017).

Negara maju diperkirakan 5.700 kasus terjadi setiap tahunnya, demam tifoid masih umum di negara berkembang dimana hal itu mempengaruhi sekitar 21,5 juta orang per tahun (CDC, 2013). Secara global diperkirakan setiap tahunnya terjadi sekitar 21 juta kasus dan 222.000 menyebabkan kematian. Demam tifoid menjadi penyebab utama terjadinya moralitas dan morbiditas di negara-negara berpenghasilan rendah dan menengah (WHO, 2016)

Profil kesehatan Indonesia tahun 2016 menunjukan angka kejadian demam typhoid sejumlah 433,2 per 100.000penduduk. Demam Thypoid disebabkan bakteri salmonellatyphi yang menyerang pencernaan. Infeksi jika mengkonsumsi makanan yang disiapkan oleh penderita demam tifoid dengan hygiene perorang yang kurang baik (tidak mencuci tangan dengan baik setelah ke toilet). Berdasarkan data dari profil Kesehatan Indonesia tahun 2012 yang di keluarkan oleh Kementrian Kesehatan Republik Indonesia 2013, demam typhoid menempati urutan ke-3 dari 10 pola penyakit terbanyak pasien rawat inap sakit di Indonesia (KemenkesRI, 2013).

Berdasarkan data yang didapat dari dinas kesehatan provinsi sumatera selatan pada tahun 2016 menunjukkan bahwa prevalensi tifoid di provinsi sumatera selatan sebesar 1,3\% (rentang: 0,5\%-2,5\%). (Profil Dinkes Sumsel, 2016)Menurut data yang diperoleh dari dinas kesehatan kota palembang, angka kejadian penyakit demam typhoid Pada Tahun 2018 sebanyak laki-laki 140 kasus, dan perempuan 522 kasus. (Dinas Kota Palembang, 2018)

Berdasarkan data yang di dapatkan dari pengambilan data awal oleh peneliti di Rs. Bhayangkara palembang, pasien demam typhoid pada tahun 2018 sebanyak 886 orang, dan padatahun 2019 daribulanJanuari - Mei berjumlah 120 orang.(Rs Bhayangkara 2019)

Penderita demam typhoid merupakan sumber utama infeksi yang selalu mengeluarkan mikroorganisme penyebab penyakit baik ketika ia sedang sakit, maupun yang sedang dalam proses penyembuhan. Penyakit ini erat kaitannya dengan hygiene pribadi dan sanitasi lingkungan, seperti higiene perorangan, hygiene makanan, lingkungan yang kumuh, kebersihan tempattempat umum yang kurang serta perilaku 
masyarakat yang tidak mendukung untuk hidup sehat (Depkes RI, 2006)

Demam tifoid atau tifus abdominalis banyak ditemukan dalam kehidupan masyarakat kita, baik perkotaan maupun di pedesaan. Penyakit ini sangat erat kaitannya dengan perilaku hidup bersih dan sehat masyarakat, lingkungan yang kumuh, kebersihan tempat-tempat umum (rumah makan, restoran) yang kurang serta perilaku masyarakat yang tidak mendukung hidup sehat. (Kemenkes RI, 2013)

Hygiene perorang merupakan ciri perilaku hidup sehat. Beberapa kebiasaan berperilaku hidup sehat antara lain kebiasaan mencuci tangan dengan sabun setelah buang air besar dan kebiasaan mencuci tangan dengan sabun sebelum makan. Peningkatan higiene perorang adalah salah satu dari program pencegahan yakni perlindungan diri terhadap penularan tifoid (Depkes RI, 2006)

Selain hygiene sanitasi, PHBS bisa berpengaruh terhadap kejadian demam tifoid sehubungan dengan pembuangan tinja kebiasaan cuci tangan sebelum makan dan kebiasaan makan diluar rumah.(wulandari papuluang 2015)

Penelitian terkait yang dilakukan oleh Batubuaya $\operatorname{dkk}(2017)$ tentang Hubungan Higiene Perorang Dan Aspek Sosial Ekonomi Dengan Kejadian Demam Tifoid Di Rumah Sakit TK.III R.W. Mongisidi Manado dengan hasil uji chi-square menunjukan bahwa terdapat hubungan antara kebiasaan mencuci tangan sebelum makan, terdapat hubungan antara kebiasaan makan di luar rumah, terdapat hubungan antara pekerjaan responden, dan terdapat hubungan antara pendapatan kepala keluarga. Dengan kejadian demam tifoid di Rumah Sakit TK.III. R.W. Mongisidi Manado.
Penelitian terkait yang dilakukan oleh Paputungan dkk (2015) tentang Hubungan Antara Perilaku Hidup Bersih Dan Sehat Dengan Kejadian Demam Tifoid Di Wilayah Kerja Puskesmas Upai Kota Mobagu Tahun 2015 dengan Hasil uji chisquaremenunjukkan bahwa terdapat hubungan antara kebiasaan mencuci tangan dengan sabun setelah buang air besar, dan kebiasaan makan di luar rumah. Dengan kejadian demam tifoid di Wilayah Kerja Ppuskesmas Upai Kota Mobagu.

Penelitian yang dilakukan oleh Chairudin dkk (2016) tentang Hubungan Antara Perilaku Hidup Bersih Dan Sehat Dengan Kejadian Demam Tifoid Di Wilayah Kerja Puskesmas Upai Kota Mobagu Tahun 2015 dengan Hasil penelitian ini menunjukan bahwa terdapat hubungan antara kebiasaan mencuci tangan setelah buang air besar, kebiasaan mencuci tangan sebelum makan, kebiasaan makan di luar rumah, dan pekerja responden dengan kejadian demam tifoid pada pasien di RSUD Noongan.

Berdasarkan studi pendahuluan yang dilakukan oleh peneliti, terhadap 5 responden pada pasien demam typhoid di Rumah Sakit Bhayangkara Palembang ternyata 3 responden $(60 \%)$ yang mengatakan mengalami sakit perut karena hygienenya yang rendah sehingga peneliti tertarik untuk melakukan penelitian tersebut.

Dari uraian latar belakang diatas peneliti tertarik melakukan penelitian tentang "Hubungan Personal Hygiene dengan kejadian Demam Typhoid DiRumah Sakit Bhayangkara Palembang tahun 2019"

\section{METODE PENELITIAN}

Penelitian ini menggunakan metode survey analitik yang mengunakan metode kuantitatif dengan pendekatan cross sectional. populasi ini adalah seluruh pasien 
yang datang ke poliklinik rawat jalan di RS Bhayangkara palembang Tahun 2019 terhitung dari bulan Januari sampai bulan Maret yang berjumlah 691 pasien di Poli Rawat Jalan. Sampel penelitian ini adalah seluruh populasi di jadikan sampling, yaitu seluruh pasien yang datang ke poliklini rawat jalan di Rs bhayangkara palembang yaitu sebanyak 87 responden. Analisa data menggunakan analisa univariat dan analisa bivariat.

\section{HASIL PENELITIAN DAN}

\section{PEMBAHASAN}

\section{Analisa Univariat}

Tabel 1 Distribusi Frekuensi Kejadian Demam Thypoid di Poli Rawat Jalan Rumah Sakit Bhayangkara Palembang tahun 2019

\begin{tabular}{cccc}
\hline No & $\begin{array}{c}\text { Kejadian Demam } \\
\text { Thypoid }\end{array}$ & $\begin{array}{c}\text { Frekuensi } \\
(\mathbf{f})\end{array}$ & $\begin{array}{c}\text { Persentase } \\
(\mathbf{\%})\end{array}$ \\
\hline 1 & Ya & 38 & 43,7 \\
\hline 2 & Tidak & 49 & 56,3 \\
\hline \multicolumn{2}{c}{ Total } & 87 & 100 \\
\hline & Dari tabel 1 diketahui dari 87
\end{tabular}

responden yang mengalami demam thypoid sebanyak 38 responden $(43,7 \%)$ lebih sedikit dibandingkan dengan responden yang tidak mengalami demam thypoid yaitu 49 responden $(56,3 \%)$.

Berdasarkan hasil analisis univariat diketahui bahwa responden yang mengalami demam thypoid sebanyak 38 responden $(43,7 \%)$ dan yang tidak mengalami demam thypoid sebanyak 49 responden $(56,3 \%)$.

Penelitian ini sejalan dengan pendapat Depkes (2006), penderita demam typhoid merupakan sumber utama infeksi yang selalu mengeluarkan mikroorganisme penyebab penyakit baik ketika ia sedang sakit, maupun yang sedang dalam proses penyembuhan. Penyakit ini erat kaitannya dengan hygiene pribadi dan sanitasi lingkungan, seperti higiene perorangan, hygiene makanan, lingkungan yang kumuh, kebersihan tempat-tempat umum yang kurang serta perilaku masyarakat yang tidak mendukung untuk hidup sehat.

Hasil penelitian ini juga sejalan dengan penelitian Batubuaya dkk (2017) tentang Hubungan Higiene Perorang Dan Aspek Sosial Ekonomi Dengan Kejadian Demam Tifoid Di Rumah Sakit TK.III R.W. Mongisidi Manado dengan hasil penelitian menunjukkan bahwa sebanyak 56 responden (50\%) mengalami demam thypoid.

Berdasarkan hasil penelitian, teori dan penelitian terkait, peneliti berasumsi bahwa angka kejadian thypoid $43,7 \%$ hal ini disebabkan oleh berbagai faktor antara lain adalah kebersihan diri dan sanitasi lingkungan, seperti higiene perorangan, hygiene makanan, lingkungan yang kumuh, kebersihan tempat-tempat umum yang kurang serta perilaku masyarakat yang tidak mendukung untuk hidup sehat.

Tabel 2 Distribusi Frekuensi Personal Hygiene Responden di Poli Rawat Jalan Rumah Sakit Bhayangkara Palembang tahun 2019

\begin{tabular}{|c|c|c|c|}
\hline No & $\begin{array}{l}\text { Personal } \\
\text { Hygiene }\end{array}$ & Frekuensi & $\begin{array}{c}\text { Persentase } \\
(\%)\end{array}$ \\
\hline 1 & Kurang baik & 29 & 33,3 \\
\hline 2 & Baik & 58 & 66,7 \\
\hline & Total & 87 & 100 \\
\hline
\end{tabular}

personal hygiene kurang baik sebanyak 29 responden $(33,3 \%)$ lebih sedikit dibandingkan dengan responden personal hygiene baik yaitu 58 responden $(66,7 \%)$.

58 responden $(66,7 \%)$.

Penelitian ini juga sejalan dengan pendapat Depkes (2006), hygiene perorang merupakan ciri perilaku hidup sehat. Beberapa kebiasaan berperilaku hidup sehat antara lain kebiasaan mencuci tangan dengan sabun setelah buang air besar dan 
kebiasaan mencuci tangan dengan sabun sebelum makan. Peningkatan higiene perorang adalah salah satu dari program pencegahan yakni perlindungan diri terhadap penularan tifoid.

Hasil penelitian ini sejalan dengan penelitian Chairudin dkk (2016) tentang Hubungan Antara Perilaku Hidup Bersih Dan Sehat Dengan Kejadian Demam Tifoid Di Wilayah Kerja Puskesmas Upai Kota Mobagu Tahun 2015 dengan Hasil penelitian ini menunjukan bahwa terdapat hubungan antara kebiasaan mencuci tangan setelah buang air besar, kebiasaan mencuci tangan sebelulm makan, kebiasaan makan di luar rumah, dan pekerja responden dengan kejadian demam tifoid pada pasien di RSUD Noongan.

Berdasarkan hasil penelitian, teori dan penelitian terkait, peneliti berasumsi bahwa personal hygiene merupakan hal penting yang harus dilakukan untuk mencegah terjadinya penyakit thypoid, hal ini karena dengan personal hygiene yang baik seseorang dapat melindungi diri terhadap penularan kuman dan bakteri penyebab penyakit.

\section{Hasil Bivariat}

Tabel 3 Hubungan Personal Hygiene Dengan Kejadian Demam Thypoid di Poli Rawat Jalan Rumah Sakit Bhayangkara Palembang tahun 2019

\begin{tabular}{|c|c|c|c|c|c|c|c|c|c|}
\hline \multirow{3}{*}{ No } & \multirow{3}{*}{$\begin{array}{l}\text { Personal } \\
\text { Hygiene }\end{array}$} & \multicolumn{4}{|c|}{$\begin{array}{c}\text { Kejadian Demam } \\
\text { Tyhpoid }\end{array}$} & \multirow{2}{*}{\multicolumn{2}{|c|}{ Jumlah }} & \multirow{3}{*}{$p$ value } & \multirow{3}{*}{$O R$} \\
\hline & & \multicolumn{2}{|c|}{ Ya } & \multicolumn{2}{|c|}{ Tidak } & & & & \\
\hline & & $\mathbf{n}$ & $\%$ & n & $\%$ & $\mathbf{n}$ & $\%$ & & \\
\hline 1 & $\begin{array}{l}\text { Kurang } \\
\text { baik }\end{array}$ & 20 & 69 & 9 & 31 & 29 & 100 & \multirow{3}{*}{0,002} & \multirow{3}{*}{4,938} \\
\hline 2 & Baik & 18 & 31 & 40 & 69 & 58 & 100 & & \\
\hline & Total & 38 & & 49 & & 87 & & & \\
\hline
\end{tabular}

Dari tabel di atas didapatkan dari 29 responden personal hygiene kurang baik yang mengalami demam thypoid sebanyak 20 responden $(69 \%)$ sedangkan dari 58 responden personal hygiene baik dan mengalami demam thypoid sebanyak 18 responden $(31 \%)$.

Dari hasil uji statistik chi square didapatkan nilai $p$ value $=0,002<\alpha=(0,05)$ yang berarti bahwa ada hubungan personal hygiene dengan kejadian demam thypoid di Poli Rawat Jalan Rumah Sakit Bhayangkara Palembang tahun 2019. Sehingga hipotesis awal yang mengatakan bahwa ada hubungan personal hygiene dengan kejadian demam thypoid diterima secara statistik.

Penelitian ini sejalan dengan pendapat Akhsin Zulkoni (2010), kuman salmonella typhi penyebab penyakit demam tifoid ini dapat ditularkan melalui makanan dan minuman sehingga apabila seseorang kurang memperhatikan kebersihan dirinya seperti mencuci tangan maka kuman salmonella typhi dapat masuk ke dalam tubuh selanjutnya akan menyebabkan sakit. Penularan tifus dapat terjadi dimana saja dan kapan saja, biasanya terjadi melalui konsumsi makanan diluar rumah atau di tempat-tempat umum, apabila makanan atau minuman yang dikonsumsi kurang bersih. Dapat juga disebabkan karena makanan tersebut disajikan oleh seorang penderita tifus laten (tersembunyi) yang kurang menjaga kebersihan saat memasak. Seseorang dapat membawa kuman tifus dalam saluran pencernaannya tanpa sakit, ini yang disebut dengan penderita laten. Penderita ini dapat menularkan penyakit tifus ini ke banyak orang seperti tukang masak di restoran. Makanan yang sering menjadi sumber penularan adalah kerang, daging, dan susu. Makanan atau minuman yang dapat menjadi sumber penularan adalah makanan atau minuman yang tidak 
dimasak dengan baik, namun, makanan yang sudah dimasak masih dapat tercemar jika kontak dengan tangan yang kotor atau air yang mengandung kuman. Karena itulah makanan jajanan harus dijaga kebersihannya agar tidak menjadi sumber penularan penyakit ini.

Penelitian ini sejalan dengan pendapat Depkes (2006), penyakit thypoid erat kaitannya dengan higiene pribadi dan sanitasi lingkungan, seperti higiene perorangan, higiene makanan, lingkungan yang kumuh, kebersihan tempat-tempat umum yang kurang serta perilaku masyarakat yang tidak mendukung untuk hidup sehat (Depkes RI, 2006)

Hasil penelitian ini sejalan dengan penelitian Paputungan $\operatorname{dkk}(2015)$ tentang Hubungan Antara Perilaku Hidup Bersih Dan Sehat Dengan Kejadian Demam Tifoid Di Wilayah Kerja Puskesmas Upai Kota Mobagu Tahun 2015 dengan hasil penelitian ini menunjukkan bahwa terdapat hubungan antara kebiasaan mencuci tangan dengan sabun setelah buang air besar $(p=0,047)$, kebiasaan makan di luar rumah $(\mathrm{p}=0,030)$.

Penelitian ini juga sejalan dengan penelitian Chairudin dkk (2016) tentang Hubungan Antara Perilaku Hidup Bersih Dan Sehat Dengan Kejadian Demam Tifoid Di Wilayah Kerja Puskesmas Upai Kota Mobagu Tahun 2015 dengan hasil penelitian ini menunjukan bahwa terdapat hubungan antara kebiasaan mencuci tangan setelah buang air besar $(p=0,033)$, kebiasaan mencuci tangan sebelum makan $(p=0,041)$, kebiasaan makan di luar rumah $(\mathrm{p}=0,015)$, dan pekerja responden $(p=0,002)$ dengan kejadian demam tifoid pada pasien di RSUD Noongan.

Berdasarkan hasil penelitian, teori dan penelitian terkait peneliti berasumsi bahwa personal hygiene kurang baik merupakan salah satu penyebab terjadinya thypoid hal ini karena kurangnya menjaga kebersihan diri, lingkungan serta makanan dapat menjadi tempat berkembang biaknya kuman salmonella typhi yang apabila masuk ke dalam tubuh dapat menyebabkan seseorang mengalami thypoid.

\section{KESIMPULAN}

1. Distribusi frekuensi responden yang mengalami demam thypoid sebanyak 38 responden $(43,7 \%)$ lebih sedikit dibandingkan dengan responden yang tidak mengalami demam thypoid yaitu 49 responden $(56,3 \%)$.

2. Distribusi frekuensi responden personal hygiene kurang baik sebanyak 29 responden (33,3\%) lebih sedikit dibandingkan dengan responden personal hygiene baik yaitu 58 responden $(66,7 \%)$.

3. Ada hubungan personal hygiene dengan kejadian demam thypoid di Poli Rawat Jalan Rumah Sakit Bhayangkara Palembang tahun 2019 dengan $p$ value $=$ 0,002 .

\section{SARAN}

Diharapkan rumah sakit dapat meningkatkan pemberian informasi kepada masyarakat tentang personal hygiene dengan memperbanyak poster atau leaflat tentang cara menjaga kebersihan diri, penyuluhan atau konseling serta dapat meningkatkan pemberian layanan kepada pasien thypoid.

Penelitian selanjutnya diharapkan dapat menggunakan variabel yang lebih bervariasi dan menggunakan metode lainnya, sehingga penelitian tentang penyakit thypoid dapat terus berkembang. 


\section{DAFTAR PUSTAKA}

Addin A, 2009.Pencegahan dan penanggulangan penyakit, Bandung: PT.Puri Delco

Arief Rakman,dkk, 2009, Faktor - Faktor Risiko yang berpengaruh terhadap kejaadian demam tifoid pada orang dewasa, berita kedokteran masyarakat,vol.25,no.4,

Desember 2009, hlm. 167-175

Aris Suyono, 2006, Hubungan Sanitasi Lingkungan Dan Higiene PeroranganDengan Kejadian Demam Tifoid Di Puskesmas Bobotsari

KabupatenPurbalingga. Skripsi : Universitas Diponegoro.

Arisman, 2008, Keracunan Makanan, Jakarta: EGC.

Depkes RI, 2006, Pedoman Pengendalian Demam Tifoid, Jakarta: DirektoratJendral PP \& PL.

, 2017, Profil Kesehatan Indonesia, Jakarta: Departemen KesehatanRepublik Indonesia..

, 2017, Profil Kesehatan Sumatera Selatan, Palembang: Dinas Kesehatan Provinsi Sumatera Selatan. , 2017, Laporan Hasil Riset Kesehatan Dasar(Riskesda) Prov. sumsel tahun 2017, Palembang: Departemen Kesehatan Republik Indonesia.

Dewi Masitoh, 2009, Hubungan antara Perilaku Higiene Perorangan denganKejadian Demam Tifoid pada pasien rawat inap di Rumah Sakit Islam SultanHadlirin Jepara. Skripsi, Universitas Negeri Semarang
Dwi Yulianingsih, 2008, Faktor Risiko Kejadian Demam Tifoid pada PenderitaUmur 15-24 Tahun di RSUD Kabupaten Temanggung Tahun 2008. Skripsi,Universitas Negeri Semarang.

Sjaifoellah Noer, dkk., 1999, Buku Ajar Ilmu Penyakit Dalam Jilid 1, Jakarta:Balai Penerbit FKUI

Soedarto, 2009, Penyakit Menular di Indonesia, Jakarta: CV Sagung Seto.

Soekidjo Notoatmojdjo, 2002, Metodologi Penelitian Kesehatan, Jakarta: RinekaCipta.

2003, Ilmu Kesehatan Masyarakat, Jakarta: RinekaCipta.

World Health Organitation, 2016, Background Document : The Diagnosis, Treatment And Prevention Of Typhoid Fever, WHO/V\&B/03.07, Geneva :World Health Organization, 2016 